\title{
A revision of Plectanocotyle (Monogenea, Plectanocotylidae), with molecular barcoding of three species and the description of a new species from the streaked gurnard Chelidonichthys lastoviza off Algeria
}

\author{
Zouhour El Mouna Ayadi ${ }^{1}$, Fadila Tazerouti ${ }^{1}$, Delphine Gey ${ }^{2}$, Jean-Lou Justine ${ }^{\text {Corresp. } 3}$ \\ 1 Faculté des Sciences Biologiques, Université des Sciences et de la Technologie Houari Boumediene, Alger, Algeria \\ 2 Molécules de Communication et Adaptation des Micro-Organismes, Museum national d'Histoire naturelle, Paris, France \\ 3 ISYEB - Institut de Systématique, Évolution, Biodiversité, Muséum National d'Histoire Naturelle, Paris, France \\ Corresponding Author: Jean-Lou Justine \\ Email address: justine@mnhn.fr
}

Background The family Plectanocotylidae includes parasites of the gills of marine fish; although 9 genera and about 20 species have been described, almost no molecular information is available. Putting aside Plectanocotyle elliptica Diesing, 1850 , supposedly a parasite of the white perch Morone americana, never found again since its original description, two species were valid within Plectanocotyle Diesing, 1850 before this work: Plectanocotyle gurnardi (Van Beneden \& Hesse, 1863) Llewellyn, 1941 and Plectanocotyle major Boudaya, Neifar \& Euzet, 2006. Methods In this paper, we describe the third species of the genus Plectanocotyle and perform a comparative morphological and molecular analysis of the three species and of Triglicola obscura (Euzet \& Suriano, 1974) Mamaev, 1976. Host fishes were also barcoded (COI) for confirmation of host identifications. Results Plectanocotyle lastovizae n. sp. is described from the gills of the streaked gurnard Chelidonichthys lastoviza collected off Algeria. The species is compared with specimens of Plectanocotyle cf. gurnardi (from C. lastoviza) from the same locality and $P$. major and T. obscura (both from the longfin gurnard C. obscurus). Molecules from Plectanocotyle cf. gurnardi could not be compared with $P$. gurnardi from the type-host and type-locality and we kept the status of the Mediterranean specimens as pending. Algeria is a new geographic record for $P$. major and $T$. obscura. Plectanocotyle lastovizae $\mathrm{n}$. sp. is distinguished from the other species found in the Mediterranean by the measurements of clamps, number of testes, and COI sequences, with notable divergence (7.8-11.8\%) from the other two species of the genus. Discussion We briefly present a list of currently known members of the family Plectanocotylidae, their biology and their hosts. 
1 A revision of Plectanocotyle (Monogenea, Plectanocotylidae), with molecular

2 barcoding of three species and the description of a new species from the

3 streaked gurnard Chelidonichthys lastoviza off Algeria

4

5 Zouhour El Mouna Ayadi ${ }^{1}$, Fadila Tazerouti ${ }^{1}$, Delphine Gey ${ }^{2}$, and Jean-Lou Justine ${ }^{3 *}$

6

$7 \quad{ }^{1}$ Faculté des Sciences Biologiques, Université des Sciences et de la Technologie Houari

8 Boumediene, Alger, Algeria

$9 \quad{ }^{2}$ Molécules de Communication et Adaptation des Micro-Organismes, Muséum national

10 d'Histoire naturelle, Paris, France

$11{ }^{3}$ ISYEB - Institut de Systématique Evolution Biodiversité, Muséum National d'Histoire

12 Naturelle, Paris, France

$13 *$ Corresponding author

14 E mail: justine@mnhn.fr 


\section{Abstract}

17 Background The family Plectanocotylidae includes parasites of the gills of marine fish; although 9 genera and about 20 species have been described, almost no molecular information is available. Putting aside Plectanocotyle elliptica Diesing, 1850, supposedly a parasite of the white perch Morone americana, never found again since its original description, two species were valid within Plectanocotyle Diesing, 1850 before this work: Plectanocotyle gurnardi (Van Beneden \& Hesse, 1863) Llewellyn, 1941 and Plectanocotyle major Boudaya, Neifar \& Euzet, 2006. Methods In this paper, we describe the third species of the genus Plectanocotyle and perform a comparative morphological and molecular analysis of the three species and of Triglicola obscura (Euzet \& Suriano, 1974) Mamaev, 1976. Host fishes were also barcoded (COI) for confirmation of host identifications. Results Plectanocotyle lastovizae n. sp. is described from the gills of the streaked gurnard Chelidonichthys lastoviza collected off Algeria. The species is compared with specimens of Plectanocotyle cf. gurnardi (from C. lastoviza) from the same locality and P. major and T. obscura (both from the longfin gurnard C. obscurus). Molecules from Plectanocotyle cf. gurnardi could not be compared with P. gurnardi from the type-host and type-locality and we kept the status of the Mediterranean specimens as pending. Algeria is a new geographic record for P. major and T. obscura. Plectanocotyle lastovizae n. sp. is distinguished from the other species found in the Mediterranean by the measurements of

34 clamps, number of testes, and COI sequences, with notable divergence (7.8-11.8\%) from the other two species of the genus. Discussion We briefly present a list of currently known members

36 of the family Plectanocotylidae, their biology and their hosts. 


\section{Introduction}

39 The Plectanocotylidae Monticelli, 1903 are a family of polyopisthocotylean monogeneans which

40 are distinguished by the structure of the clamps, having a large unpaired accessory piece

41 (Yamaguti 1963). In addition, all plectanocotylids have a fixed number of clamps (6 or 8) and

42 their male copulatory organ consists of a sheaf of long spines. The Plectanocotylidae currently

43 include nine genera and all species are parasites of marine teleost fishes (WoRMS 2021). Two

44 species are currently valid in the genus Plectanocotyle Diesing, 1850: Plectanocotyle gurnardi

45 (Van Beneden \& Hesse, 1863) Llewellyn, 1941 and Plectanocotyle major Boudaya, Neifar \&

46 Euzet, 2006 (Boudaya et al. 2006; Llewellyn 1941; Van Beneden \& Hesse 1863); both are

47 parasites on the gills of triglid fish (gurnards). The type-species of the genus, Plectanocotyle

48 elliptica Diesing, 1850, was described from the white perch Morone americana (Gmelin, 1789),

49 a member of the Moronidae, but was not found again since its original description. We consider

50 here that only the two species mentioned above were valid before this work; the status of $P$.

51 elliptica is discussed later in this article.

52 In this paper, we report the finding of a third species of the genus, found off Algeria on the gills

53 of the streaked gurnard Chelidonichthys lastoviza. We compared the morphology of our new

54 species to two other species, collected at the same place, and we performed a molecular analysis

55 of three species of the genus and of Triglicola obscura (Euzet \& Suriano, 1974) Mamaev, 1976,

56 a species also found on one of the hosts studied here. We collected specimens of a species which

57 could be attributed to $P$. gurnardi; however, its host was different from the type-host (C.

58 lastoviza vs. Eutrigla gurnardus) and the locality was different from the type-locality

59 (Mediterranean vs North Sea); therefore, we designate this species as Plectanocotyle cf. gurnardi 
60 throughout this study but do not discuss it further in the absence of molecular information from

$61 \quad$ P. gurnardi from its type-host and type-locality.

62 The host fish were also barcoded, and we applied rigorous methods to ensure traceability of both

63 fish and monogenean specimens and adequate barcoding (COI) of both hosts and parasites.

64 We also briefly discuss a list of currently known Plectanocotylidae, their biology and their hosts.

65 This paper is part of a series on monogeneans of fishes of the South shore of the Mediterranean

66 Sea (i.e. (Ayadi et al. 2017; Azizi et al. 2021; Boudaya \& Neifar 2016; Bouguerche et al. 2019a,

67 b, c, 2020a, b, 2021; Chaabane et al. 2015, 2016a, b, 2017; Kheddam et al. 2016, 2020) ).

\section{Materials and Methods}

69 Fish

70 Gurnards, fifty Chelidonichthys lastoviza (Bonnaterre, 1788) and eighty Chelidonichthys

71 obscurus (Walbaum, 1792) were collected from Bouharoun, Algerian coast $\left(36^{\circ} 37^{\prime} 24.17^{\prime \prime} \mathrm{N}, 2^{\circ}\right.$

$7239^{\prime} 17.38^{\prime \prime}$ E). Fish were dead when purchased. Fish specimens were identified using keys

73 (Fischer et al. 1987) and transferred to the laboratory shortly after capture. Gills were removed

74 carefully from each fish and observed under a microscope for the presence of monogeneans.

\section{Monogeneans}

76 Monogeneans were removed alive from gills, dehydrated, stained with acetic carmine and

77 mounted in Canada balsam according to routine methods (Ayadi et al. 2017). Some specimens

78 were examined in Berlese fluid. Drawings were made with the help of an Olympus BH-2

79 microscope drawing tube, then scanned and redrawn on a computer with Adobe Illustrator.

80 Measurements are in micrometres. 


\section{Traceability of fish, monogenean specimens and host-parasite relationships}

82 For the molecular study, we ensured that hosts and monogeneans were labelled with respect to

83 host-parasites relationships, i.e. complete traceability. A tissue sample of the fish was taken and

84 several monogeneans were extracted; each monogenean was cut in two halves, the posterior half

85 being processed for molecular analysis and the anterior being kept for morphological assessment

86 and preparation of a voucher slide. This ensures that the molecular identification of the host fish

87 and their monogenean parasites correspond perfectly (Ayadi et al. 2017; Azizi et al. 2021;

88 Bouguerche et al. 2019a, b, c, 2020b, 2021; Justine et al. 2013), at the individual fish and

89 parasite level (Table 1). Slides were deposited in the Muséum National d'Histoire Naturelle,

90 Paris, France (MNHN), under registration numbers MNHN HEL1652-HEL1750.

\section{Molecular barcoding of fish}

92 Total genomic DNA was isolated using a QIAamp DNA Mini Kit (Qiagen), as per the

93 manufacturer's instructions. The 5' region of the mitochondrial cytochrome c oxidase subunit I

94 (COI) gene was amplified with the primers FishF1 and FishR1 (Ward et al. 2005). PCR reactions

95 and amplification were performed as in Ayadi et al. (2017). We used CodonCode Aligner

96 version 3.7.1 software (CodonCode Corporation, Dedham, MA, USA) to edit sequences, which

97 were $655 \mathrm{bp}$ in length, compared them to the GenBank database content with BLAST, and

98 deposited them in GenBank under accession numbers MG761757-MG761759 and MW788679-

99 MW788687 (Table 1). Species identification was confirmed with the BOLD identification

100 engine (Ratnasingham \& Hebert 2007).

\section{COI sequences of monogeneans}

102 Total genomic DNA was isolated using a QIAmp DNA Micro Kit (Qiagen). The specific primers

103 JB3 (= COI-ASmit1) and JB4.5 (= COI-ASmit2) were used to amplify a fragment of $424 \mathrm{bp}$ of 
104 the COI gene (Bowles et al. 1995; Littlewood et al. 1997). PCR reactions and amplification were

105 performed as in Ayadi et al. (2017). Sequences were edited with CodonCode Aligner 3.7.1,

106 compared to the GenBank database content with BLAST, and deposited in GenBank under

107 accession numbers MG761760-MG761766 and MW796584-MW796594.

108 Trees and distances

109 Two matrices were constructed, for delimitation of taxa and phylogeny.

110 The first matrix was built from all our new sequences and the few COI sequences of

111 plectanocotylids already in GenBank. In particular, we used COI sequences from

112 plectanocotylids collected off Sète, on the Mediterranean coast of France (Jovelin \& Justine

113 2001). Since the Family Mazocraeidae is considered close to the Plectanocotylidae in

114 phylogenies (Olson \& Littlewood 2002), we used a sequence of a mazocraeid as outgroup; the

115 COI sequence with the best coverage with our sequences was found within the complete

116 mitogenome of Neomazocraes dorosomatis (Yamaguti, 1938) Price, 1943 (JQ038229,

117 unpublished sequence by Zhang, Wu, Xie \& Li). On this matrix with 21 sequences, after

118 estimating the best model with MEGA7 (Kumar et al. 2016), a tree was inferred using the

119 Maximum Likelihood method based on the Hasegawa-Kishino-Yano model with Gamma

120 distribution $(\mathrm{HKY}+\mathrm{G})$ in MEGA7, with 1000 bootstrap replications (Hasegawa et al. 1985). The

121 sequences were 396 bases in length, but the analysis was on only 312 positions because of some

122 indels and incomplete coverages of some sequences.

123 A second matrix was built from the first by deleting all sequences with indels or missing parts.

124 The second matrix had only 15 sequences, but all taxa of the first matrix were represented. All

125 sequences were perfectly clean: there were 396 positions in the dataset for sequences which were 
126396 bases in length. After estimating the best model with MEGA7, a tree was inferred using the

127 Maximum Likelihood method based on the Hasegawa-Kishino-Yano model with Gamma

128 distribution $(\mathrm{HKY}+\mathrm{G})$ in MEGA7, with 1000 bootstrap replications (Hasegawa et al. 1985). A

129 tree was also inferred with the Neighbour-Joining method with MEGA7 with 1000 bootstrap

130 replications.

131 Distances were computed on MEGA7 on the second "clean" matrix, using the MEGA7 "group"

132 feature for convenience (groups were defined on the basis of clades found in the analysis).

133 Kimura-2 and $p$-distances were computed, for comparison with other studies.

\section{Nomenclature}

135 The electronic version of this article in Portable Document Format (PDF) will represent a

136 published work according to the International Commission on Zoological Nomenclature (ICZN),

137 and hence the new names contained in the electronic version are effectively published under that

138 Code from the electronic edition alone. This published work and the nomenclatural acts it

139 contains have been registered in ZooBank, the online registration system for the ICZN. The

140 ZooBank LSIDs (Life Science Identifiers) can be resolved and the associated information viewed

141 through any standard web browser by appending the LSID to the prefix http://zoobank.org/. The

142 LSID for this publication is: urn:lsid:zoobank.org:pub:B6FB3B21-138D-49AD-B0D6-

143 456AC3F7D36E. The online version of this work is archived and available from the following

144 digital repositories: PeerJ, PubMed Central and CLOCKSS. 


\section{Results}

\section{Molecular identification of fish}

147 The identification of fish species based on morphology was confirmed by a DNA barcoding

148 approach. BLAST analysis of the COI sequences with the NCBI and BOLD databases showed

149 sequence similarity values close to $100 \%$, thus confirming the morphological identifications

150 (Table 1).

\section{Molecular characterization of monogeneans}

152 A tree built from the first matrix, which included all available COI sequences of

153 Plectanocotylidae (our 18 new sequences and 2 already in GenBank) and 1 Mazocraeidae,

154 provided the following results (Figure 1). The analysis involved 21 nucleotide sequences, and

155 there were a total of 312 positions in the final dataset. The purpose of this matrix with all

156 sequences was to see whether it was possible to attribute the available sequences to separate taxa,

157 and to verify the identity of sequences from GenBank. The answer was positive; the ML tree

158 showed several clades with $100 \%$ bootstrap support and each clade corresponded to a nominal

159 species identified from morphology. The Plectanocotyle cf. gurnardi clade included 8 sequences,

160 all new. The $P$. major clade included 3 sequences, all new. The $P$. lastovizae clade included 3

161 new sequences and the sequence labelled "Plectanocotyle sp" in GenBank (AY009169). The $T$.

162 obscura clade included 3 new sequences and the sequence labelled "Octoplectanocotyla

163 obscurum" in GenBank (AY009170). Although the analysis provided high bootstrap values for

164 species nodes, the higher nodes had very low values, and Triglicola was not a sister-group to

165 Plectanocotyle. We considered that low bootstrap values were caused by the presence of many

166 indels in some sequences. 
167 The second matrix was built by excluding from the first matrix all sequences with indels or

168 incomplete coverage, to improve the accuracy of the final analysis; the matrix, including 15

169 sequences, was perfectly clean, with 396 positions for 396 base-long sequences. Excluded

170 sequences were the old sequences from 2001 (Jovelin \& Justine 2001) and a few of our new

171 sequences. The ML tree built from the second matrix (Figure 2) showed the same four

172 plectanocotylid taxa, with $T$. obscura as a sister-group to a clade including the three

173 Plectanocotyle species. The NJ tree based on the same matrix had an identical topology. As in

174 the first analysis, support for each species was high (98-99 ML, $100 \mathrm{NJ})$. Supports for higher

175 nodes were higher than in the first analysis, albeit still relatively low. The support for the

176 Plectanocotyle clade (sister-group to Triglicola) was low in ML (54) but relatively high in NJ

177 (75). Within this clade, $P$. cf. gurnardi was the sister-group to a clade (88ML, $90 \mathrm{NJ})$ including

178 the two sister-groups P. lastovizae and P. major.

179 Distances were computed on the basis of the second matrix (Table 2). Variation was low within

180 each species (P. cf. gurnardi, 0.220\% and 0.221\%; P. major, 0.509\% and $0.512 \%$; P. lastovizae,

$1810.678 \%$ and $0.684 \%$, respectively for $\mathrm{p}$-distance and Kimura-2 distances). The three sequences of

182 T. obscura were identical (variation 0\%). Distances between species were high, at 7.80\% and

$1838.31 \%$ between $P$. lastovizae and P. major, and at $12.55 \%$ and $13.82 \%$ between $P$. major and $T$.

184 obscura (each time for p-distance and Kimura-2 distances, respectively)

185 These results strongly suggest that the three species found in Algerian marine waters,

186 Plectanocotyle lastovizae n. sp., Plectanocotyle major and Plectanocotyle cf. gurnardi, are

187 distinct at the molecular level, with interspecific distances ranging between 7.8 and 11.8\%.

188 Molecular results justify description of a new species, in addition to the morphological

189 differences between species. 
190 Description of Plectanocotyle lastovizae n. sp.

191 urn:lsid:zoobank.org:act:1BF3310A-3B95-472E-AD39-8289B2D01368

192

193 Description (based on 31 specimens) (Figure 3; measurements in Table 3).

194 Body flattened dorsoventrally. Total length $2120(1100-3000, n=31)$, width at level of ovary 310

195 (200-430, n=31). Haptor symmetrical, with three pairs of pedunculate clamps that measure 125

196 (90-180, n=11). Each clamp formed by an anterior and posterior jaw; we use the nomenclature of

197 Llewellyn (1956) (Llewellyn 1956). Anterior jaw composed of a median sclerite 'a' 60 (51-70,

$198 \mathrm{n}=12)$ in length which passes to the posterior jaw and two sclerites ' $b$ ' $75(63-85, \mathrm{n}=12)$ in length

199 that maintain the edges of the clamp. Posterior jaw formed of two sclerites 'c' $63(52-95, \mathrm{n}=12)$

200 in length shaped as quarter circles. Posterior jaw is also supported by sclerite 'a' which forms an

201 enlargement posteriorly and is followed by two sclerites 'd' $20(12-26, \mathrm{n}=5)$ in length and 'e' 25

$202(15-32, \mathrm{n}=11)$ in length. Terminal lappet $265(160-375, \mathrm{n}=19)$ long and $42(25-70, \mathrm{n}=19)$ wide,

203 with two pairs of median and lateral hamuli and uncinuli at posterior extremity. Median hamuli

$20454(45-60, n=12)$ long, with little guard and blade; lateral hamuli $54(42-62, \mathrm{n}=12)$ with a

205 large guard and blade; two uncinuli $9(5-13, \mathrm{n}=7)$ long.

206

207

208

209

210

211

Mouth subterminal, ventral. Two hemispherical buccal suckers, 34 (25-45) $(n=15)$ in diameter.

Median pharynx, small, $48(38-60, n=15)$ in length and $42(30-56, n=15)$ in width. Short

oesophagus. Intestine bifurcate, branches with medial and lateral caeca, extending into posterior region of the haptor, not confluent posteriorly.

Testes $13(11-15)(n=15)$ in number in one to two rows. Testes $63(45-83)(n=16)$ long and 65 $(40-90)(n=16)$ wide. Vas deferens median, dorsal. Male copulatory organ with 8 peripheral 
212 slender spines, $112(90-162)(n=19)$ long and 2 median spines, $78(57-90)(n=18)$ long. Male

213 accessory glands and two correspondent reservoirs one on each side of male copulatory organ.

214 Ovary tubular, turned back on itself in mid-region of body. Oviduct directed anteriorly. Oötype

215 marked by Mehlis Glands. Vitelline follicles are well developed and located on each side of the

216 body. Uterus ventral and median. Eggs $151(143-161)(n=10)$ long, with one posterior polar

217 filament.

218 Taxonomic summary

219 Synonym: Plectanocotyle sp. of Jovelin \& Justine, 2001 (Jovelin \& Justine 2001)

Type host: Chelidonichthys lastoviza (Bonnaterre, 1788)

221

Type locality: Off Bouharoun, near Alger, Algeria ( $\left.36^{\circ} 37^{\prime} 24.17^{\prime \prime} \mathrm{N}, 2^{\circ} 39^{\prime} 17.38^{\prime \prime} \mathrm{E}\right)$,

222 Mediterranean Sea.

223

Other locality: off Sète, France, Mediterranean Sea (from similarity of sequences, see

224 discussion).

225

Microhabitat: gills

226

Prevalence: $48 \%$ ( 24 infected/50 examined)

227

Type material: Holotype, MNHN HEL1652; paratypes, 43 slides MNHN HEL1653-

228

HEL1695 (specimens in Canada balsam); vouchers in picrate, 12 slides, MNHN HEL1696-

229

HEL1707; vouchers of specimens used for molecular barcoding, i.e. slides with anterior part of

230 monogeneans, 4 slides, MNHN HEL1723-HEL1726 (Table 1). 
232 lastoviza. used for molecular barcoding generally exceed the number of sequences (Table 1) because some 235 specimens did not yield usable sequences. slides, vouchers deposited in MNHN, MNHN HEL1711-HEL1722; vouchers of specimens used for molecular barcoding, i.e. slides with anterior part of monogeneans, 10 slides including 4 with sequence, MNHN HEL1723-HEL1726 (Table 1). We do not designate these specimens as $P$. gurnardi (Van Beneden \& Hesse, 1863) because their host was different from the type-host $(C$.

241 lastoviza vs. Eutrigla gurnardus) and their locality was different from the type-locality

242 (Mediterranean vs North Sea). In the absence of molecular information from specimens of $P$.

243 gurnardi from its type-host and type-locality, we provisorily keep the status of this species as

244 pending but remark that it could well be a distinct species. We have recently collected specimens

245 from the type-host to test this hypothesis; this will be the subject of a distinct paper. 268HG-271HG, TJ146-Tj149bis; paratype from off Sfax, Tunisia, MNHN 272HG, Tj150. In 248 all type specimens but one, the length of the MCO spines ranges from 112 to $125 \mu \mathrm{m}$, which 249 corresponds to the original description $(90-120 \mu \mathrm{m})$, but curiously, specimen $271 \mathrm{HG}$ from Sète 250 has spines $195 \mu \mathrm{m}$ in length; this specimen was not in an optimal state and other characters could 251 not be studied. Specimens from C. obscurus, off Bouharoun, Algeria, 3 slides, vouchers 252 deposited in MNHN, MNHN HEL1708-HEL1710. Vouchers of specimens used for molecular 
253 barcoding, i.e. slides with anterior part of monogeneans, 5 slides including 3 with sequence,

254 MNHN HEL1735-HEL1737 (Table 1).

Triglicola obscura. Holotype and paratype of Plectanocotyloides obscurum from

256 Chelidonichthys obscurus, off Sète, France, MNHN 164TC, Tj178 and Tj179. Vouchers of

257 specimens from Chelidonichthys obscurus, off Bouharoun, Algeria, used for molecular

258 barcoding, i.e. slides with anterior part of monogeneans, 6 slides including 3 with sequence

259 MNHN HEL1738-HEL1740 (Table 1). For this species, we checked that the length of the spines

260 of the MCO $(180-210 \mu \mathrm{m})$ corresponded with those of the type specimens (our measurements:

$261170 \mu \mathrm{m}$ in both; original description: $175-185 \mu \mathrm{m})$. When looking at our voucher slides with

262 only the anterior part, this species can be easily distinguished from the three other species

263 mentioned here by this characteristic alone, which does not overlap (length in all three

264 Plectanocotyle species: 90-125 $\mu \mathrm{m})$.

265 Discussion

266 Differential diagnosis of Plectanocotyle lastovizae $\mathbf{n}$. sp.

267 Plectanocotyle lastovizae n. sp. differs from P. cf. gurnardi by the morphology and size of

268 clamps ( $125 \times 101$ vs $94 \times 82 \mu \mathrm{m})$, the length of terminal lappet $(265 \times 42$ vs $77 \times 52)$ and the

269 size of the sclerites of terminal lappet (54 vs 43); the most outstanding differential characters are

270 the morphology and size of clamps and the number of testes (13 vs 23).

271 Plectanocotyle lastovizae $\mathrm{n}$. sp. differs from P. major by the size of clamps (125 x 101 vs $181 \mathrm{x}$

$272139 \mu \mathrm{m})$, the size of terminal lappet ( $265 \times 42$ vs $61 \times 40)$, the size of the lateral hamuli of 
273 terminal lappet (54 vs 77); the most outstanding differential character is the number of testes (13

274 vs 20).

275 The three species of Plectanocotyle are also distinguished by significant differences in their COI

276 sequences; it is worth mentioning here that our molecular study encompasses all currently known

277 members of the genus (with the exception of $P$. gurnardi if our specimens designated as $P$. cf.

278 gurnardi do not actually belong to this species). Bouguerche et al. (2019a) compiled results

279 about intraspecific and interspecific variation of COI sequences in polyopisthocotylean

280 monogeneans and found that intraspecific differences ranged $0.2-5.6 \%$; the sequence differences

281 found within each taxon in our study are low enough to be consistent with intraspecific

282 differences, and the differences between taxa exceed the interspecific threshold.

283 It is frequent in monogenean taxonomy to distinguish species by measurements of the copulatory

284 organs; we note that this does not apply to the three species of Plectanocotyle, which all have 285 spines of the MCO ranging from 90 to $125 \mu \mathrm{m}$ (with rare measurements up to $162 \mu \mathrm{m}$ ), with 286 overlapping lengths.

287 New and other localities for Plectanocotyle spp. and T. obscura

288 Since the sequence deposited by Jovelin \& Justine (Jovelin \& Justine 2001) as "Plectanocotyle

289 sp." from material collected off the Mediterranean coast of France coast off Sète, from the same

290 host, is very similar to our sequences of the Algerian material, it is likely that P. lastovizae is

291 present on both the North and South shores of the Mediterranean. Therefore, off Sète, France, is

292 considered an additional locality for P. lastovizae, for which the type-locality is off Algeria.

293 Sequences from a phylogeny (Jovelin \& Justine 2001) produced from the same animals are

294 curiously labelled in GenBank with two names; although designated in the text and GenBank 
295 "details" as Plectanocotyloides obscurum, they are currently labelled as both Plectanocotyloides 296 obscurum (28S, AF311718) and "Octoplectanocotyla obscura" (COI, AY009170). The current

297 binomial designation of this species is Triglicola obscura (Euzet \& Suriano, 1974) Mamaev,

298 1976. The type-locality of T. obscura is off Sète, France; similarity of our COI sequences with

299 this sequence indicates the presence of T. obscura off Algeria.

300 The present records of $P$. major (type-locality, off Sète, France) and T. obscura are first records

301 for Algeria. Plectanocotyle major has also been recorded from Tunisia (Boudaya et al. 2006, 302 2020).

303 There are several records of P. gurnardi in the North Sea (i.e. (Køie 2000; Llewellyn 1941;

304 Pugachev \& Fagerholm 1995)); hosts are generally Eutrigla gurnardus, with a mention in

305 Chelidonichthys cuculus (Llewellyn 1941). In the Mediterranean, the mentions of P. gurnardi

306 from its type-host, E. gurnardus, off Sète, France are probably valid (Jovelin \& Justine 2001;

307 Tuzet \& Ktari 1971). In addition, Plectanocotyle gurnardi has been recorded from another host,

308 Chelidonichthys lucerna (Linnaeus, 1758) (as Trigla lucerna) in the Black Sea (Pogorel'tseva

309 1964) and in the Mediterranean off Turkey (Akmirza 2013). In the absence of molecular

310 information, we do not know if this species from C. lucerna is the same as our $P$. cf. gurnardi

311 and if it is actually $P$. gurnardi. There is also a mention of $P$. gurnardi on Chelidonichthys

312 lastoviza (as Trigla lineata) off Greece (Papoutsoglou 2016) which could be either our new

313 species $P$. lastovizae or the species we designated here as $P$. cf. gurnardi.

\section{Nomenclatural status of Plectanocotyle and its species}

315 The nomenclatural status of Plectanocotyle requires some explanation. Plectanocotyle elliptica

316 Diesing, 1850 was described from specimens found on the gills of the White Perch Morone 
317 americana (as Labrax mucronatus), a Moronidae from North America (Diesing 1850), but was

318 never found again on the same host. Phyllocotyle gurnardi van Beneden \& Hesse, 1863 was

319 described from the gills of Eutrigla gurnardus (Triglidae) collected off Belgium (Van Beneden

320 \& Hesse 1863). Plectanocotyle lorenzii Monticelli, 1899 was described from Trigla sp. in the

321 Mediterranean Sea (Monticelli 1899), and Plectanocotyle caudata Lebour, 1908 was described

322 from Eutrigla gurnardus in the North Sea (Lebour 1908). Llewellyn detailed this complex

323 taxonomical situation and concluded (Llewellyn 1941) that Plectanocotyle gurnardi (van

324 Beneden \& Hesse, 1863) Llewellyn, 1941 was the valid taxon parasitic on the gills of Eutrigla

325 gurnardus (and Eutrigla cuculus). Sproston followed that opinion, provided a detailed report of

326 the taxonomic contradictions and redescribed specimens at various states of maturity and

327 contraction (Sproston 1946). Price followed Sproston (Price 1961). Several major authors,

328 including Sproston, Bychowsky and Price (Bychowsky 1961; Price 1961; Sproston 1946)

329 pointed out that Plectanocotyle elliptica Diesing, 1850 was never found again and that no

330 Plectanocotyle species was ever found again outside the Triglidae. We can therefore consider

331 that nomenclatural issues have been solved in the past and this indicates that species of

332 Plectanocotyle are parasitic only on Triglidae. We note, however, that $P$. elliptica is still

333 considered valid in the WoRMS database (WoRMS 2021).

334 Within Plectanocotyle, because of the synonymies proposed by Llewelyn, only two species were 335 recognized before our study (Llewellyn 1941): Plectanocotyle gurnardi (Van Beneden \& Hesse, 336 1863) Llewellyn, 1941 and Plectanocotyle major Boudaya, Neifar \& Euzet, 2006 (Gibson \&

337 Bray 2001). However, Boudaya et al. (2006) mentioned that they collected specimens in the

338 Mediterranean Sea from Chelidonichthys cuculus (as Triglus cuculus) and Chelidonichthys

339 lastoviza (as Trigla lineata) which belonged to a third species but they did not describe them 
340 (Boudaya et al. 2006). Jovelin \& Justine (2001) using specimens examined by Euzet from off

341 Sète (France, Mediterranean Sea), sequenced partial 28S from Plectanocotyle gurnardi from

342 Eutrigla gurnardus and Plectanocotyle sp. from Chelidonichthys lastoviza, and COI from the

343 latter monogenean; unfortunately no COI sequence was published from $P$. gurnardi (Jovelin \&

344 Justine 2001).

345 In this study, we considered that the two Plectanocotyle species found on C. lastoviza

346 corresponded to a species similar to a known species, $P$. gurnardi, and a new one, $P$. lastovizae.

347 On the basis of host alone, we could have considered the two species from C. lastoviza as two

348 new species, but we preferred a conservative approach. We understand that our identification of

349 the species as "P. cf. gurnardi" should be challenged by a molecular and morphological study of

350 specimens from the type-host and type-locality of P. gurnardi.

\section{Hosts and biology of species of Plectanocotylidae}

352 According to WoRMS (WoRMS 2021), there are 9 valid genera in the Plectanocotylidae. Euzet

353 \& Trilles described Octolabea turchinii Euzet \& Trilles, 1960 and assigned it to the

354 Plectanocotylidae on the basis of the clamp structure (Euzet \& Trilles 1960). Yamaguti

355 considered Octolabea as the type of his new family Octolabeidae Yamaguti, 1963 (Yamaguti

356 1963). Later, Euzet \& Suriano considered that Octolabea should be kept within the

357 Plectanocotylidae, thus rending the Octolabeidae invalid (Euzet \& Suriano 1973). In addition,

358 Euzet \& Suriano considered that Octoplectanocotyla Yamaguti, 1937 was not a member of the

359 Plectanocotylidae because of the structure of its clamps and because its hosts, fishes of the

360 family Trichiuridae, were different from the hosts of other plectanocotylids (Euzet \& Suriano

361 1973). Mamaev and various collaborators created a series of new genera in the 1970's, based on

362 the study of fishes from the Pacific which were not examined by previous authors. Table 4 
363 summarizes the species known and their hosts; it is based on WoRMS (9 genera) with the

364 addition of Octolabea and the exclusion of Plectanocotyloides, considered a synonym of

365 Triglicola according to Mamaev (Mamaev 1976); we provisionally keep Octoplectanocotyla,

366 thus reaching a total of 9 genera and 20 valid species.

367 In the family Plectanocotylidae (Table 4), members of Plectanocotyle and Triglicola are parasitic

368 of fishes of the family Triglidae (gurnards) and members of Adenicola, Octolabea and

369 Peristedionelia are parasites of Peristediidae (armoured gurnards); both Triglidae and

370 Peristediidae are Scorpaeniformes. However, members of Octodiplectanocotyla are on

371 Trichiuridae (cutlassfishes, Perciformes), members of Inversocotyle are on Acropomatidae

372 (lanternbellies, Perciformes), members of Triglicoloides are on Chlorophthalmidae

373 (Aulopiformes), and members of Euzeplectanocotyle are on Trachichthyidae (Slimeheads,

374 Beryciformes). We do not include the Moronidae within this list since we consider that the

375 record of P. elliptica from Morone americana (Diesing 1850) was erroneous (Bychowsky 1961;

376 Price 1961; Sproston 1946). Finally, the family Plectanocotylidae includes species parasitic on a

377 wide variety of Teleostei: Perciformes, Scorpaeniformes, Aulopiformes and Beryciformes.

378 For most of the species described by Mamaev, we found no record in addition to the original

379 description, but Euzetplectanocotyle hoplosteti was mentioned again on its type-host Hoplosteus

380 mediterraneus in the Mediterranean off Valencia, Spain (Hernández-Orts et al. 2016). Studies on

381 members of Plectanocotyle which do not pertain to taxonomy are scarce but varied: they

382 included an interpretation of the attachment of the clamps to the gills (Llewellyn 1956),

383 observations on nutrition (Halton \& Jennings 1965) and the chemical nature of attachment

384 sclerites (Lyons 1966), a description of the egg, miracidium and hatching (Whittington \& Kearn

385 1989), ultrastructural descriptions of the epidermis (Lyons 1972), clamp sclerites (Shaw 1979) 
386 and spermatozoon (Tuzet \& Ktari 1971), and fish stock discrimination (Boudaya et al. 2020). A

387 molecular phylogeny (Jovelin \& Justine 2001) placed Plectanocotyle gurnardi together with

388 Plectanocotyle sp. (clearly P. lastovizae in view of the similarity of COI sequences) and

389 Triglicola obscura in a monophyletic Plectanocotylidae. 
391

392

393

394

395

396

397

398

399

400

401

402

403

404

405

406

407

408

409

410

411

412

413

414

415

416

417

418

419

420

421

422

423

424

425

426

\section{References}

Akmirza A. 2013. Monogeneans of fish near Gökçeada, Turkey. Turkish Journal of Zoology $37: 441-448$.

Ayadi ZEM, Gey D, Justine J-L, and Tazerouti F. 2017. A new species of Microcotyle (Monogenea: Microcotylidae) from Scorpaena notata (Teleostei: Scorpaenidae) in the Mediterranean Sea. Parasitology International 66:37-42.

Azizi R, Bouguerche C, Santoro M, Gey D, Tazerouti F, Justine J-L, and Bahri S. 2021. Redescription and molecular characterization of two species of Pauciconfibula (Monogenea, Microcotylidae) from trachinid fishes in the Mediterranean Sea. Parasitology Research 120:2363-2377.

Boudaya L, Feki M, Mosbahi N, and Neifar L. 2020. Stock discrimination of Chelidonichthys obscurus (Triglidae) in the central Mediterranean Sea using morphometric analysis and parasite markers. Journal of Helminthology 94:e74.

Boudaya L, and Neifar L. 2016. Triloculotrema euzeti n. sp. (Monogenea, Monocotylidae) from the nasal tissues of the blackspotted smooth-hound Mustelus punctulatus (Carcharhiniformes, Triakidae) from off Tunisia. Parasite 23:62.

Boudaya L, Neifar L, and Euzet L. 2006. Plectanocotyle major sp. n. (Monogenea: Plectanocotylidae), a gill parasite of Chelidonichthys obscurus (Teleostei: Triglidae) from the Mediterranean Sea. Folia Parasitologica 53:53.

Bouguerche C, Gey D, Justine J-L, and Tazerouti F. 2019a. Microcotyle visa n. sp. (Monogenea: Microcotylidae), a gill parasite of Pagrus caeruleostictus (Valenciennes) (Teleostei: Sparidae) off the Algerian coast, Western Mediterranean. Systematic Parasitology 96:131-147.

Bouguerche C, Gey D, Justine J-L, and Tazerouti F. 2019b. Towards the resolution of the Microcotyle erythrini species complex: description of Microcotyle isyebi $\mathrm{n}$. sp. (Monogenea, Microcotylidae) from Boops boops (Teleostei, Sparidae) off the Algerian coast. Parasitology Research 118:1417-1428.

Bouguerche C, Justine J-L, and Tazerouti F. 2020a. Redescription of Flexophora ophidii Prost \& Euzet, 1962 (Monogenea: Diclidophoridae) from Ophidion barbatum (Ophidiidae) off the Algerian coast, Mediterranean Sea. Systematic Parasitology 97:827-833.

Bouguerche C, Tazerouti F, Gey D, and Justine J-L. 2019c. Redescription and molecular characterisation of Allogastrocotyle bivaginalis Nasir \& Fuentes Zambrano, 1983 (Monogenea: Gastrocotylidae) from Trachurus picturatus (Bowdich, 1825) (Carangidae) off the Algerian coast, Mediterranean Sea. Systematic Parasitology 96:681-694.

Bouguerche C, Tazerouti F, Gey D, and Justine J-L. 2020b. No vagina, one vagina, or multiple vaginae? An integrative study of Pseudaxine trachuri (Monogenea, Gastrocotylidae) 
leads to a better understanding of the systematics of Pseudaxine and related genera. Parasite 27:50.

Bouguerche C, Tazerouti F, Gey D, and Justine J-L. 2021. Triple barcoding for a hyperparasite, its parasitic host, and the host itself: a study of Cyclocotyla bellones (Monogenea) on Ceratothoa parallela (Isopoda) on Boops boops (Teleostei). Parasite 28:48.

Bowles J, Blair D, and McManus DP. 1995. A molecular phylogeny of the human schistosomes. Molecular Phylogenetics and Evolution 4:103-109.

Bychowsky BE. 1961. Monogenetic Trematodes their systematics and phylogeny. English translation edited by W. J. Hargis Jr. Washington: American Institute of Biological Sciences.

Carvalho ARd, and Luque JL. 2012. Three new species of monogeneans parasitic on Atlantic cutlassfish Trichiurus lepturus (Perciformes: Trichiuridae) from Southeastern Brazil. Acta Scientiarum Biological Sciences 34.

Chaabane A, Justine J-L, Gey D, Bakenhaster MD, and Neifar L. 2016a. Pseudorhabdosynochus sulamericanus (Monogenea, Diplectanidae), a parasite of deep-sea groupers (Serranidae) occurs transatlantically on three congeneric hosts (Hyporthodus spp.), one from the Mediterranean Sea and two from the western Atlantic. PeerJ 4:e2233.

Chaabane A, Neifar L, Gey D, and Justine J-L. 2016b. Species of Pseudorhabdosynochus (Monogenea, Diplectanidae) from groupers (Mycteroperca spp., Epinephelidae) in the Mediterranean and Eastern Atlantic Ocean, with special reference to the "beverleyburtonae group" and description of two new species. PLoS ONE 11:e0159886.

Chaabane A, Neifar L, and Justine J-L. 2015. Pseudorhabdosynochus regius n. sp. (Monogenea, Diplectanidae) from the mottled grouper Mycteroperca rubra (Teleostei) in the Mediterranean Sea and Eastern Atlantic. Parasite 22:9.

Chaabane A, Neifar L, and Justine J-L. 2017. Diplectanids from Mycteroperca spp. (Epinephelidae) in the Mediterranean Sea: Redescriptions of six species from material collected off Tunisia and Libya, proposal for the 'Pseudorhabdosynochus riouxi group', and a taxonomic key. PLoS ONE 12:e171392.

Diesing CM. 1850. Systema helminthum, Vol. I. Vindobonae: Wilhemum Braumüller.

Euzet L, and Suriano DM. 1973. Plectanocotyloides obscurum n. g., n. sp. (Monogenea) parasite branchial d'Aspitrigla obscura (Téléostéen) en Méditerranée. Bulletin du Muséum National d'Histoire Naturelle, 3e série, Zoologie 137:807-813.

Euzet L, and Trilles J-P. 1960. Octolabea turchinii n. g., n. sp. (Plectanocotylidae) un monogène nouveau, parasite de Peristhedion cataphractum (L.). Annales de Parasitologie Humaine et Comparee 35:504-508. 
462 Fischer W, Bauchot M-L, and Schneider M. 1987. Fiches FAO d'identification des espèces pour

463

464

465

466

467

468

469

470

471

472

473

474

475

476

477

478

479

480

481

482

483

484

485

486

487

488

489

490

491

492

493

494

495

496

497

les besoins de la pêche. (Révision 1). Méditerranée et mer Noire. Zone de pêche 37. Volume II. Vertébrés. Publication préparée par la FAO, résultat d'un accord entre la FAO et la Commission des Communautés Européennes (Projet GCP/INT/422/EEC) financée conjointement par ces deux organisations. Rome, FAO, Vo1.2: 761-1530.

Gibson DI, and Bray RA. 2001. Plectanocotyle Diesing, 1850. Accessed through: World Register of Marine Species at http://www.marinespecies.org/aphia.php?p=taxdetails\&id=119390 on 2017-12-08.

Halton DW, and Jennings JB. 1965. Observations on the nutrition of Monogenetic Trematodes. Biological Bulletin 129:257-272.

Hasegawa M, Kishino H, and Yano T-a. 1985. Dating of the human-ape splitting by a molecular clock of mitochondrial DNA. Journal of Molecular Evolution 22:160-174.

Hernández-Orts JS, Juan-García A, and Kuchta R. 2016. Diversity of monogeneans of deep-sea sharks and fish from the western Mediterranean deep-sea. In: Benovics M, Kobikova Z, and Gelnar M, editors. 5th Workshop of the Euopean Centre of Ichthyoparasitology. Prušánky, Czech Republic.

Jovelin R, and Justine J-L. 2001. Phylogenetic relationships within the polyopisthocotylean monogeneans (Platyhelminthes) inferred from partial 28S rDNA sequences. International Journal for Parasitology 31:393-401.

Justine J-L, Rahmouni C, Gey D, Schoelinck C, and Hoberg EP. 2013. The monogenean which lost its clamps. PLoS ONE 8:e79155.

Kheddam H, Chisholm LA, and Tazerouti F. 2020. Septitrema lichae n. g., n. sp. (Monogenea: Monocotylidae) from the nasal tissues of the deep-sea kitefin shark, Dalatias licha (Bonnaterre) (Squaliformes: Dalatiidae), off Algeria. Systematic Parasitology 97:553559.

Kheddam H, Justine J-L, and Tazerouti F. 2016. Hexabothriid monogeneans from the gills of deep-sea sharks off Algeria, with the description of Squalonchocotyle euzeti $\mathrm{n}$. sp. (Hexabothriidae) from the kitefin shark Dalatias licha (Euselachii, Dalatiidae). Helminthologia 53:354-362.

Køie M. 2000. Metazoan parasites of teleost fishes from atlantic waters off the Faroe Islands. Ophelia 52:25-44.

Kumar S, Stecher G, and Tamura K. 2016. MEGA7: Molecular Evolutionary Genetics Analysis version 7.0 for bigger datasets. Molecular Biology and Evolution 33:1870-1874.

Lebour MV. 1908. Fish trematodes of the Northumberland coast. Reports of the Scientific Investigation of the Northumberland Sea Fisheries for 1907. Newcastle-upon-Tyne: Cail \& Sons. 
498

499

500

501

502

503

504

505

506

507

508

509

510

511

512

513

514

515

516

517

518

519

520

521

522

523

524

525

526

527

528

529

530

531

Littlewood DTJ, Rohde K, and Clough KA. 1997. Parasite speciation within or between host species? - Phylogenetic evidence from site-specific polystome monogeneans. International Journal for Parasitology 27:1289-1297.

Llewellyn J. 1941. The taxonomy of the monogenetic trematode Plectanocotyle gurnardi (v. Ben. \& Hesse). Parasitology 33:431-432.

Llewellyn J. 1956. The adhesive mechanisms of monogenetic trematodes - the attachment of Plectanocotyle gurnardi (V. Ben. \& Hesse) to the gills of Trigla. Journal of the Marine Biological Association of the United Kingdom 35:507-514.

Lyons KM. 1966. The chemical nature and evolutionary significance of monogenean attachment sclerites. Parasitology 56:63-101.

Lyons KM. 1972. Ultrastructural observations on the epidermis of the polyopisthocotylinean monogeneans Rajonchotyle emarginata and Plectanocotyle gurnardi. Zeitschrift für ParasitenKunde 40:87-100.

Mamaev YL. 1976. Triglicola australis sp. n. (Monogenea: Plectanocotylidae), a parasite from fishes of the Tasman Sea [in Russian, English summary]. (For English translation see Soviet Journal of Marine Biology 2(6):388-390.). Biologiya Morya 2:52-54.

Mamaev YL, and Aljoshkina LD. 1984. [Four new species of Monogeneans of tropical zones of the Atlantic Ocean]. In "Parasites of Animals and Plants", pp 25-34 Institute of Biology and Pedology, Far-Eastern Science Centre, Vladivostok, USSR (In Russian).

Mamaev YL, and Parukhin AM. 1972a. [New Monogenea of the family Plectanocotylidae Poche] (English title: Monogeneans of the family Plectanocotylidae Poche, 1926, new representative of the subfamily Plectanocotylinae). Parazitologiia 6:65-74.

Mamaev YL, and Parukhin AM. 1972b. [New subfamily Adenicolinae subfam. n. (Monogenoidea, Plectanocotylidae)] (English title: A new subfmamily Adenicolinae Subfam. n. (Monogenoidea: Plectanocotylidae)). Parazitologiia 6:259-268.

Mamaev YL, and Tkachuk LP. 1979. [Euzetplectanocotyle hoplosteti gen. et sp. nov., a new monogenean representative of the family Plectanocotylidae (Monogenea)]. Biologiya Morya 6:72-75.

Monticelli F. 1899. Di una nuova specie del genere Plectanocotyle. Atti della Accademia delle Scienze di Torino 34:1045-1053.

Olson PD, and Littlewood DTJ. 2002. Phylogenetics of the Monogenea - evidence from a medley of molecules. International Journal for Parasitology 32:233-244.

Papoutsoglou SE. 2016. Metazoan parasites of fishes from Saronicos gulf, Athens-Greece. Thalassographica 1:69-102.

Peer) reviewing PDF | (2018:02:24095:3:0:NEW 7 Jan 2022) 
532 Pascoe PL. 1987. Monogenean parasites of deep-sea fishes from the Rockall Trough (N. E.

533 Atlantic) including a new species. Journal of the Marine Biological Association of the

$534 \quad$ United Kingdom 67:603-622.

535

536

537

538

539

540

541

542

543

544

545

546

547

548

549

550

551

552

553

554

555

556

557

558

559

560

561

562

563

564

565

Pogorel'tseva TP. 1964. [New and little known species of monogenetic trematodes of fish in the Black Sea]. Problemy Parazitologii (Trudy Ukraine Republic Nauchno Obshchestva Parazitologia) 3:30-42.

Price EW. 1961. North American monogenetic trematodes. IX. The families Mazocraeidae and Plectanocotylidae. Proceedings of the Biological Society of Washington 74:127-156.

Pugachev O, and Fagerholm H-P. 1995. A bibliography and an index list on parasites and parasitic diseases of fish in Northern Europe. Åbo: Åbo Akademi.

Ratnasingham S, and Hebert PDN. 2007. BOLD: The Barcode of Life Data System (www. barcodinglife. org). Molecular Ecology Notes 7:355-364.

Shaw MK. 1979. The ultrastructure of the clamp sclerites in Gastrocotyle trachuri and other clamp-bearing monogeneans. Zeitschrift für ParasitenKunde 59:43-51.

Sproston N. 1946. A synopsis of the monogenetic trematodes. Transactions of the Zoological Society of London 25:185-600.

Tuzet O, and Ktari M-H. 1971. Recherches sur l'ultrastructure du spermatozoïde de quelques Monogènes. Bulletin de la Société Zoologique de France 96:535-540.

Van Beneden PJ, and Hesse CE. 1863. Recherches sur les Bdellodes (Hirudinées) et les Trématodes marins. Mémoires de l'Académie Royale des Sciences, des Lettres et des Beaux-Arts de Belgique 34:1-150 + Plates.

Ward RD, Zemlak TS, Innes BH, Last PR, and Hebert PD. 2005. DNA barcoding Australia's fish species. Philosophical Transactions of the Royal Society of London B Biological Sciences 360:1847-1857.

Whittington ID, and Kearn GC. 1989. Rapid hatching induced by light intensity reduction in the polyopisthocotylean monogenean Plectanocotyle gurnardi from the gills of gurnards (Triglidae), with observations on the anatomy and behaviour of the oncomiracidium. Journal of the Marine Biological Association of the United Kingdom 69:609-624.

WoRMS. 2021. Plectanocotylidae Monticelli, 1903. Accessed at: http://www.marinespecies.org/aphia.php?p=taxdetails\&id=119249 on 2021-09-28.

Yamaguti S. 1937. Studies on the helminth fauna of Japan. Part 19. Fourteen new ectoparasitic trematodes of fishes: Printed by the author.

Yamaguti S. 1963. Systema Helminthum Volume IV Monogenea and Aspidocotylea: John Wiley \& Sons.

Peer) reviewing PDF | (2018:02:24095:3:0:NEW 7 Jan 2022) 
566 Zhang JY, Yang TB, and Liu L. 2001. (Monogeneans of Chinese marine fishes). Beijing: 567 Agriculture Press.

568

569 


\section{Table $\mathbf{1}$ (on next page)}

Fish and monogeneans, and their morphological and molecular identifications

Note that traceability was ensured by labelling and barcoding fish individuals and their respective monogenean parasites. New data include 8 new sequences of fish and 18 new sequences of monogeneans. 


\begin{tabular}{|c|c|c|c|c|c|c|c|}
\hline $\begin{array}{l}\text { Fish } \\
\text { id }\end{array}$ & $\begin{array}{l}\text { Fish } \\
\text { morphological } \\
\text { identification }\end{array}$ & $\begin{array}{l}\text { Fish } \\
\text { COI GenBank } \\
\#\end{array}$ & $\begin{array}{l}\text { Fish } \\
\text { molecular identification (BOLD) }\end{array}$ & $\begin{array}{l}\text { Monogenean } \\
\text { id }\end{array}$ & $\begin{array}{l}\text { Monogenean } \\
\text { morphological identification }\end{array}$ & $\begin{array}{l}\text { Monogenean } \\
\text { COI GenBank \# }\end{array}$ & $\begin{array}{l}\text { Monogenean } \\
\text { slides } \\
\text { deposited }\end{array}$ \\
\hline \multirow[t]{3}{*}{$\mathrm{Br} 23$} & Chelidonichthys lastoviza & MG761757 & Chelidonichthys lastoviza $99.84 \%$ & $\mathrm{Br} 23 \mathrm{Mo} 1$ & Plectanocotyle lastovizae $\mathrm{n} . \mathrm{sp}$. & MG761760 & HEL1723 \\
\hline & & & & $\mathrm{Br} 23 \mathrm{Mo} 2$ & Plectanocotyle lastovizae n. sp. & MG761761 & HEL1724 \\
\hline & & & & $\mathrm{Br} 23 \mathrm{Mo} 3$ & Plectanocotyle lastovizae n. sp. & MG761762 & HEL1725 \\
\hline \multirow[t]{2}{*}{$\operatorname{Br} 26$} & Chelidonichthys lastoviza & MG761758 & Chelidonichthys lastoviza $100 \%$ & Br26Mo1 & Plectanocotyle cf. gurnardi & MG761763 & HEL1727 \\
\hline & & & & Br26Mo3 & Plectanocotyle cf. gurnardi & MG761764 & HEL1728 \\
\hline \multirow[t]{3}{*}{$\mathrm{Br} 29$} & Chelidonichthys obscurus & MG761759 & Chelidonichthys obscurus $99.69 \%$ & Br29Mo1 & Triglicola obscura & MG761765 & HEL1738 \\
\hline & & & & $\mathrm{Br} 29 \mathrm{Mo} 2$ & Triglicola obscura & MG761766 & HEL1739 \\
\hline & & & & Br29Mo3 & Triglicola obscura & MW796584 & HEL 1740 \\
\hline Br 30 & Chelidonichthys lastoviza & MW788679 & Chelidonichthys lastoviza $100 \%$ & Br30Mo1 & Plectanocotyle lastovizae n. sp. & MW796585 & HEL 1726 \\
\hline \multirow[t]{3}{*}{ Br 31} & Chelidonichthys lastoviza & MW788680 & Chelidonichthys lastoviza $100 \%$ & $\mathrm{Br} 31 \mathrm{Mo} 3$ & Plectanocotyle cf. gurnardi & MW796586 & HEL1729 \\
\hline & & & & $\mathrm{Br} 31 \mathrm{Mo} 4$ & Plectanocotyle cf. gurnardi & MW796587 & HEL1730 \\
\hline & & & & $\mathrm{Br} 31 \mathrm{Mo} 5$ & Plectanocotyle cf. gurnardi & MW796588 & HEL1731 \\
\hline \multirow[t]{3}{*}{$\operatorname{Br} 32$} & Chelidonichthys lastoviza & MW788681 & Chelidonichthys lastoviza $100 \%$ & $\mathrm{Br} 32 \mathrm{Mo} 1$ & Plectanocotyle cf. gurnardi & MW796589 & HEL1732 \\
\hline & & & & $\mathrm{Br} 32 \mathrm{Mo} 2$ & Plectanocotyle cf. gurnardi & MW796590 & HEL1733 \\
\hline & & & & $\mathrm{Br} 32 \mathrm{Mo} 3$ & Plectanocotyle cf. gurnardi & MW796591 & HEL1734 \\
\hline Br 33 & Chelidonichthys obscurus & MW788682 & Chelidonichthys obscurus $99.85 \%$ & Br33Mo1 & Plectanocotyle major & MW796592 & HEL1735 \\
\hline Br 36 & Chelidonichthys obscurus & - & - & $\mathrm{Br} 36 \mathrm{Mo} 1$ & Plectanocotyle major & MW796593 & HEL1736 \\
\hline Br 37 & Chelidonichthys obscurus & MW788685 & Chelidonichthys obscurus $100 \%$ & $\mathrm{Br} 37 \mathrm{Mo1}$ & Plectanocotyle major & MW796594 & HEL1737 \\
\hline
\end{tabular}

2 In addition, some fish were barcoded but monogenean sequences from the same fish were not retrieved. These were registered in

3 GenBank as: MW788683: Br34 Chelidonichthys obscurus 100\%; MW788684: Br35 Chelidonichthys obscurus 99.85\%; MW788686:

$4 \mathrm{Br} 38$ Chelidonichthys obscurus 100\%; and MW788687: Br39 Chelidonichthys obscurus 99.69\% (percentages are BOLD similarity).

5 Some monogeneans with voucher slides did not provide molecular sequences (slides HEL1741-1750). 


\section{Table 2 (on next page)}

Genetic distances between COI sequences of Monogeneans

Distances are percentages based on the matrix including only clean sequences. Kimura-2 and p-distances are indicated. Italics: distance within species. Distances within species are low, ranging from 0 to $0.68 \%$; distances between species are high, ranging from 7.80 to $13.82 \%$. 


\begin{tabular}{lllll}
\hline p-distances & P. lastovizae & P. major & P. cf. gurnardi & T. obscura \\
\hline Plectanocotyle lastovizae & 0.678 & & & \\
Plectanocotyle major & 7.80 & 0.509 & & \\
Plectanocotyle cf. gurnardi & 10.90 & 10.30 & 0.220 & \\
Triglicola obscura & 11.87 & 12.55 & 11.75 & 0.000 \\
Kimura-2 distances & $\boldsymbol{P .}$ lastovizae & $\boldsymbol{P .}$ major & $\boldsymbol{P}$. cf. gurnardi & T. obscura \\
Plectanocotyle lastovizae & 0.684 & & & \\
Plectanocotyle major & 8.31 & 0.512 & & \\
Plectanocotyle cf. gurnardi & 11.83 & 11.11 & 0.221 & \\
Triglicola obscura & 13.00 & 13.82 & 12.99 & 0.000 \\
\hline
\end{tabular}




\section{Table 3(on next page)}

Measurements of species of Plectanocotyle

Measurements of three species of Plectanocotyle collected off Algeria are provided, with a comparison with P. major from Tunisia 


\begin{tabular}{|c|c|c|c|c|}
\hline & Plectanocotyle lastovizae $\mathrm{n} . \mathbf{s p}$. & Plectanocotyle cf. gurnardi & Plectanocotyle major & Plectanocotyle major \\
\hline Hosts & Chelidonichthys lastoviza & Chelidonichthys lastoviza & Chelidonichthys obscurus & Chelidonichthys obscurus \\
\hline Localities & Algeria & Algeria & Algeria & Tunisia \\
\hline Source & Present study & present study & present study & Boudaya et al. 2006 \\
\hline Body length & $2120 \pm 350(1100-3000, \mathrm{n}=31)$ & $2330 \pm 260(1900-2800, \mathrm{n}=24)$ & $4020(3380-4400, n=5)$ & $1841(1500-2300, \mathrm{n}=11)$ \\
\hline Body width & $310 \pm 50(200-430, \mathrm{n}=31)$ & $366 \pm 41(250-430, n=24)$ & $472(370-850, \mathrm{n}=5)$ & $442(210-600, n=11)$ \\
\hline Buccal organ length & $38(30-46, n=15)$ & $41(29-53, \mathrm{n}=21)$ & $60(58-62, n=4)$ & \\
\hline Buccal organ width & $34(25-45, \mathrm{n}=15)$ & $30(20-73, \mathrm{n}=21)$ & $59(55-62, \mathrm{n}=4)$ & $48(40-60, n=22)$ \\
\hline Pharynx length & $48(38-60, n=15)$ & $60(50-77, \mathrm{n}=21)$ & $69(68-70, n=4)$ & \\
\hline Pharynx width & $42(30-56, n=15)$ & $56(45-70, \mathrm{n}=21)$ & $69(67-70, n=4)$ & $45(30-70, n=24)$ \\
\hline Clamp length & $125(90-180, \mathrm{n}=11)$ & $94(80-103, \mathrm{n}=10)$ & $181(175-195, \mathrm{n}=5)$ & $137(90-160, n=17)$ \\
\hline Clamp width & $101(35-135, \mathrm{n}=11)$ & $82(70-90, \mathrm{n}=8)$ & $139(125-160, \mathrm{n}=5)$ & $110(85-140, n=17)$ \\
\hline Sclerites ' $a$ ' length & $60(51-70, \mathrm{n}=12)$ & $53(42-60, \mathrm{n}=10)$ & $89(88-90, n=5)$ & $80(75-90, n=21)$ \\
\hline Sclerites ' $b$ ' length & $75(63-85, \mathrm{n}=12)$ & $76(60-84, n=10)$ & $127(123-132, \mathrm{n}=5)$ & $157(140-180, n=21)$ \\
\hline Sclerites 'c' length & $63(52-95, \mathrm{n}=12)$ & $61(49-76, \mathrm{n}=10)$ & $83(80-90, \mathrm{n}=5)$ & $72(65-90, n=21)$ \\
\hline Sclerites 'd' length & $20(12-26, \mathrm{n}=5)$ & $27(20-35, \mathrm{n}=8)$ & $32(30-35, \mathrm{n}=5)$ & $67(55-70, \mathrm{n}=21)$ \\
\hline Sclerites 'e' length & $25(15-32, n=11)$ & $30(26-32, n=7)$ & $28(27-28, \mathrm{n}=2)$ & $33(25-40, n=21)$ \\
\hline Terminal lappet length & $265(160-375, \mathrm{n}=19)$ & $77(50-115, \mathrm{n}=10)$ & $61(56-75, \mathrm{n}=5)$ & $56(40-80, \mathrm{n}=13)$ \\
\hline Terminal lappet width & $42(25-70, \mathrm{n}=19)$ & $52(40-62, \mathrm{n}=10)$ & $40(36-45, n=5)$ & $42(30-50, n=13)$ \\
\hline Median hamulus length & $54(45-60, \mathrm{n}=12)$ & $35(20-51, \mathrm{n}=10)$ & $74(27-86, n=5)$ & $32.5(25-40, n=16)$ \\
\hline Lateral hamulus length & $54(42-62, n=12)$ & $43(23-53, n=10)$ & $77(37-88, \mathrm{n}=5)$ & $33(30-35, n=16)$ \\
\hline Postero-lateral uncinulus length & $9(5-13, \mathrm{n}=7)$ & $11(6-15, \mathrm{n}=10)$ & $17(8-20, n=5)$ & $12(10-15, \mathrm{n}=13)$ \\
\hline MCO, Peripheral spine length & $112(90-162, n=19)$ & $107(90-125, \mathrm{n}=11)$ & $113(112-114, \mathrm{n}=5)$ & $107(90-120, n=25)$ \\
\hline MCO, Median spine length & $78(57-90, \mathrm{n}=18)$ & $83(75-97, \mathrm{n}=11)$ & $75(73-76, \mathrm{n}=5)$ & $102(85-110, n=21)$ \\
\hline Number of testes & $13(11-15, \mathrm{n}=15)$ & $23(14-35, \mathrm{n}=9)$ & $20(19-20, n=5)$ & $21(19-22, n=11)$ \\
\hline Testis length & $63(45-83, \mathrm{n}=16)$ & $69(50-115, \mathrm{n}=8)$ & $86(75-100, n=5)$ & $57(30-70, \mathrm{n}=30)$ \\
\hline Testis width & $65(40-90, n=16)$ & $68(45-86, \mathrm{n}=8)$ & $73(50-86, \mathrm{n}=5)$ & $76(50-90, n=30)$ \\
\hline Egg length & $151(143-161, \mathrm{n}=10)$ & $147(143-150, n=2)$ & - & $146(120-185, \mathrm{n}=25)$ \\
\hline
\end{tabular}




\section{Table 4 (on next page)}

Species of Plectanocotylidae and their hosts

Nine genera were recognized in the family Plectanocotylidae Monticelli, 1903 in WoRMS

(2021) but after Mamaev we consider that Plectanocotyloides is a junior synonym of Triglicola. We include Octolabea, although it was separated from the Plectanocotylidae by Yamaguti (1963). Genera are in alphabetical order. Finally, this table includes 9 genera and 20 species. 


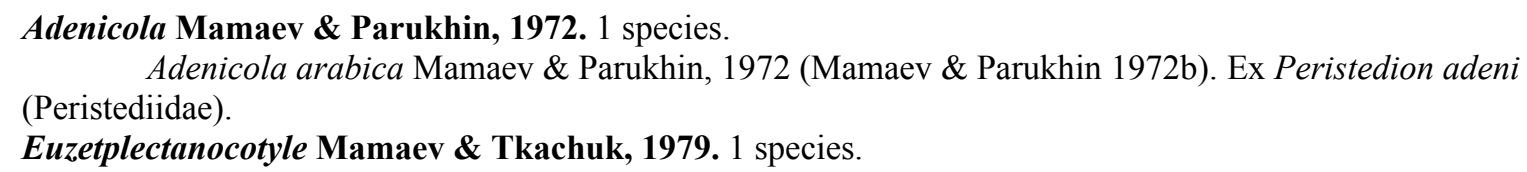

Triglicola dissimmetrica Mamaev \& Parukhin, 1972 (Mamaev \& Parukhin 1972a). Ex Lepidotrigla faurei (as Lepidotrigla natalensis) (Triglidae). (Triglidae).

Triglicola ocellata Mamaev \& Parukhin, 1972 (Mamaev \& Parukhin 1972a). Ex Lepidotrigla sp. hirundo.

Triglicola ovovivipara Mamaev \& Aleshkina, 1984 (Mamaev \& Aljoshkina 1984). Ex Chelidonichthys

Triglicola obscura (Euzet \& Suriano, 1974) Mamaev, 1976 (Euzet \& Suriano 1973; Mamaev 1976). Ex Chelidonichthys obscurus (as Aspidotrigla obscura) (Triglidae). Synonyms: Plectanocotyloides obscurum Euzet \& Suriano, 1974; Octoplectanocotyla obscurum, label used in GenBank for sequence originally deposited as Plectanocotyloides obscurum (Jovelin \& Justine 2001).

Triglicoloides Mamaev \& Parukhin, 1972. 1 species.

Triglicoloides indicus Mamaev \& Parukhin, 1972 (Mamaev \& Parukhin 1972a). Ex Chlorophthalmus agassizi (Chlorophthalmidae) 


\section{Figure 1}

Molecular phylogenetic analysis of all available members of the Plectanocotylidae

The tree was obtained by the ML method from COI sequences. All available sequences were used (18 new sequences +3 from GenBank). Each species is represented by a clade with high bootstrap value. The two sequences from monogeneans collected in France (Jovelin \& Justine, 2011) are assigned each to a clade: "Plectanocotyle sp." to the $P$. lastovizae clade, and "Octoplectanocotyla obscurum" to the Triglicola obscura clade. Bootstrap values for nodes higher than species are low; Triglicola obscura is not a sister-group to Plectanocotyle in this tree. Scale: base differences per site.

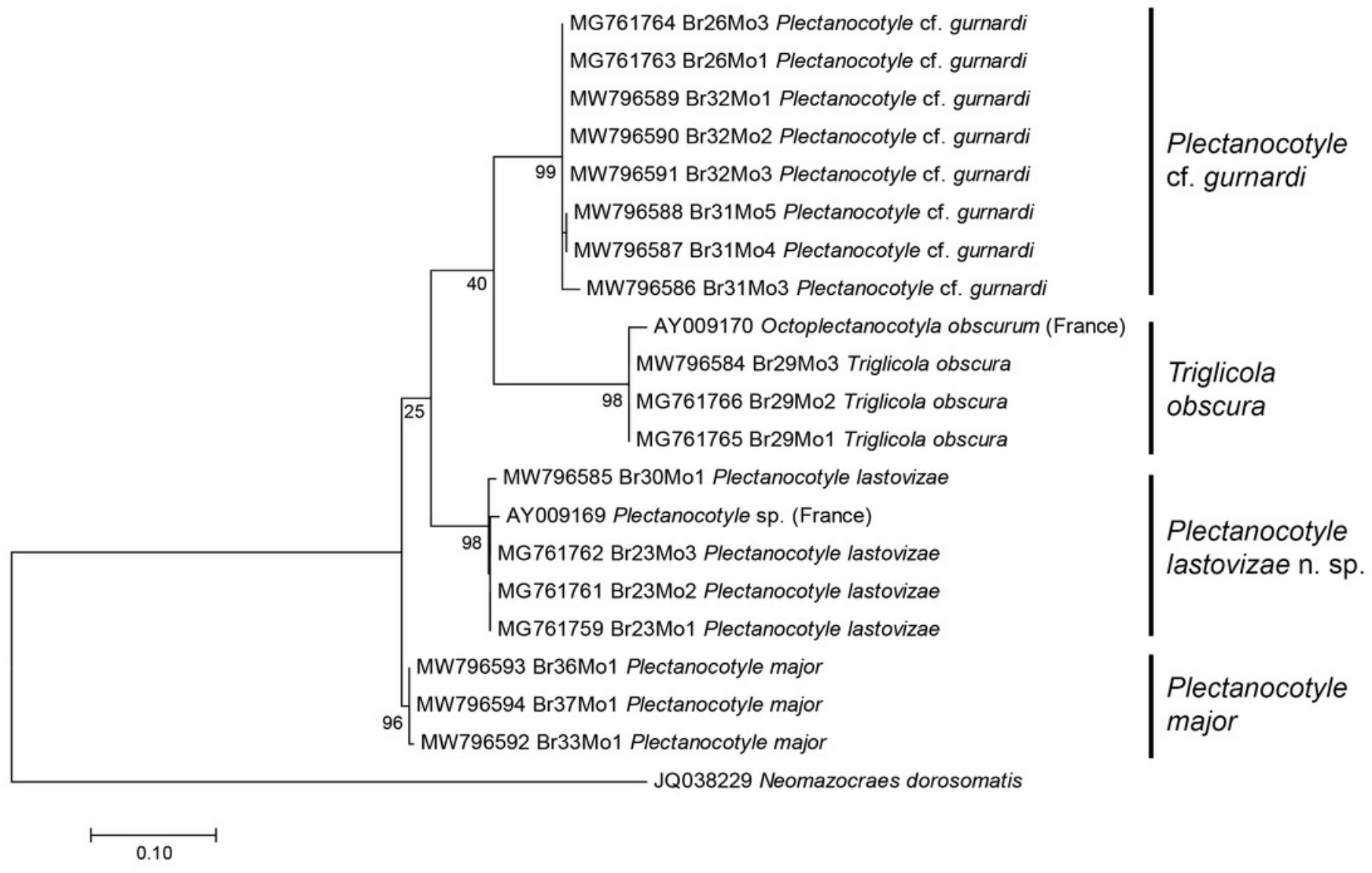




\section{Figure 2}

Molecular phylogenetic analysis of selected members of the Plectanocotylidae.

Only clean COI sequences were selected and the dataset had 396 positions for sequences 396 base pairs in length. The tree was obtained by the Maximum Likelihood method and a similar tree was obtained by the NJ method; bootstrap values for ML below branches, for NJ above branches. Each nominal species is represented by a distinct clade with high bootstrap values (97-99 ML; $100 \mathrm{NJ}$ ). Plectanocotyle lastovizae is sister-group to P. major (90 ML; 88 NJ). A sister-group relationship between Triglicola obscura and a clade formed by the three Plectanocotyle species was found, but with low values (54 ML; 75 NJ). Scale: base differences per site.

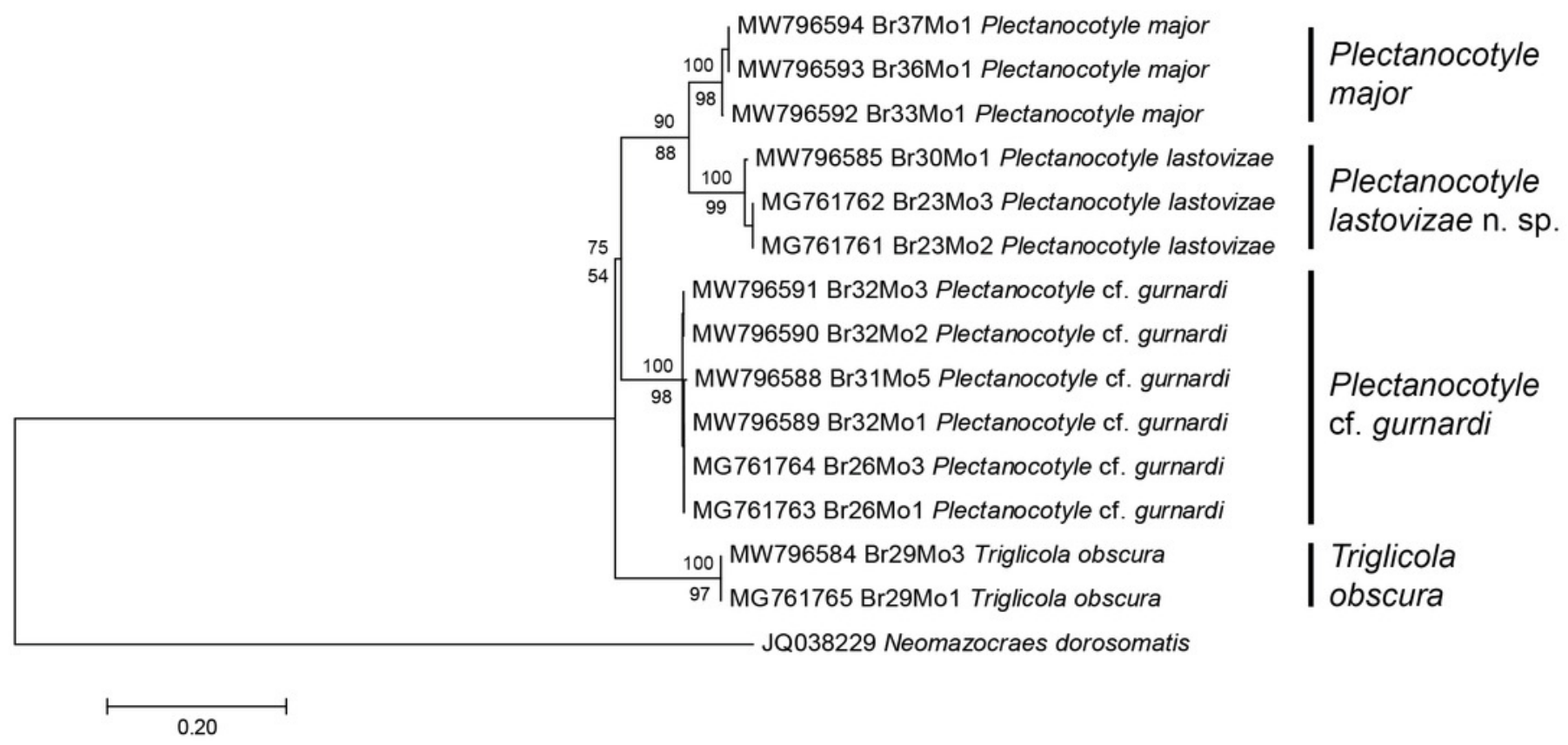


Figure 3

Plectanocotyle lastovizae n. sp. from Chelidonichthys lastoviza and comparison with other species

A-D, Plectanocotyle lastovizae, holotype; E, F, Plectanocotyle major; G, H, Plectanocotyle cf. gurnardi. A, habitus; $B, E, G$, spines of the male copulatory organ; C, F, H, clamp; D, terminal lappet. 


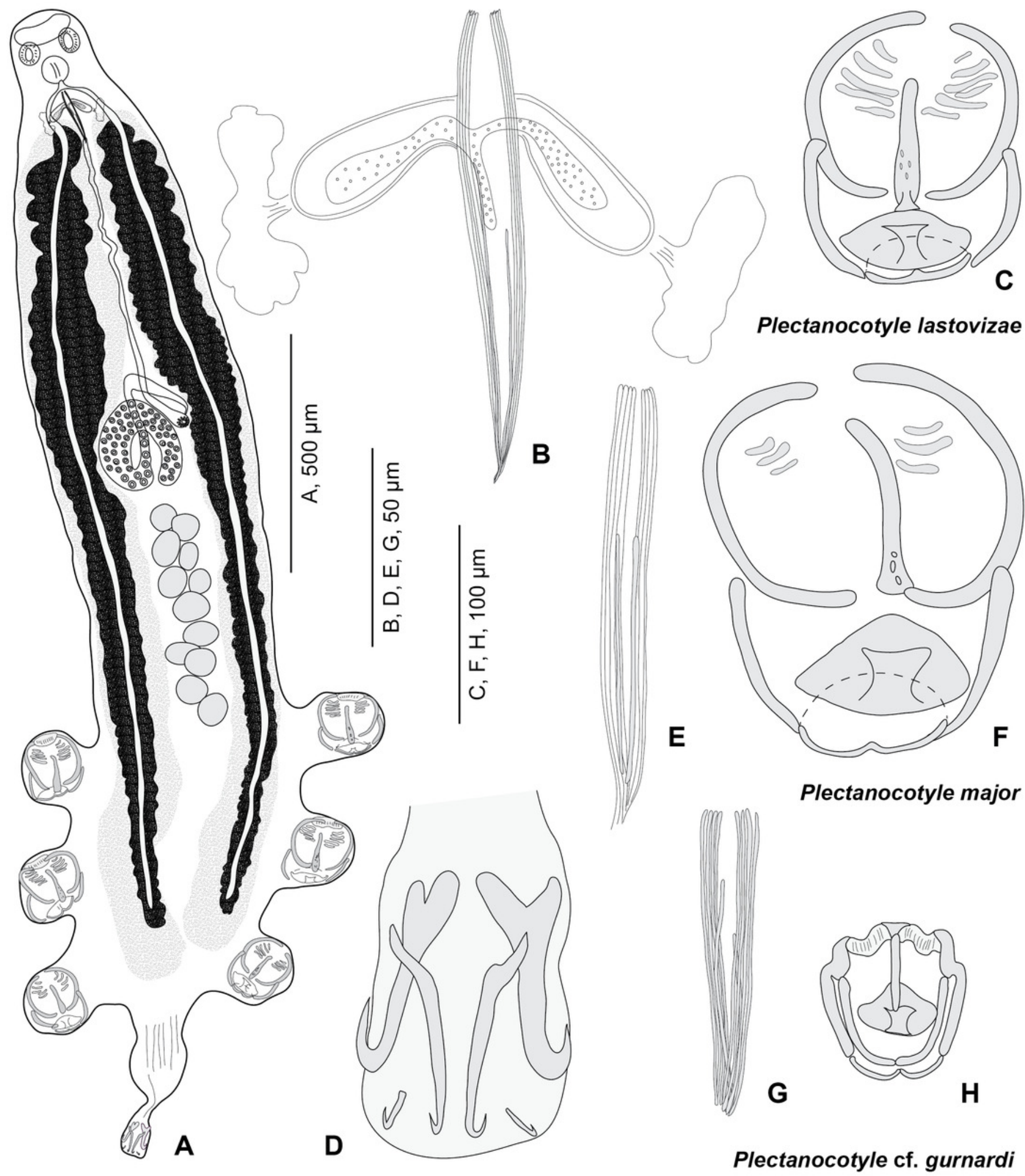

